\title{
Rediscovery of Holothuriophilus tomentosus (Ortmann) comb. nov. (Crustacea, Brachyura, Pinnotheridae) in the Brazilian coast
}

\author{
Gustavo Augusto S. de Melo ${ }^{1} \&$ Guisla Boehs ${ }^{2}$
}

\author{
${ }^{1}$ Museu de Zoologia da Universidade de São Paulo. Avenida Nazareth 481, Ipiranga, 04263-000 São Paulo, São Paulo, \\ Brasil. Bolsista do CNPq. E-mail: gasmelo@usp.br \\ 2 Departamento de Aqüicultura, CCA, Universidade Federal de Santa Catarina. Rodovia Ademar Gonzaga 1346, 88040-900 \\ Florianópolis, Santa Catarina, Brasil. Bolsista do CNPq. E-mail: guisla@cca.ufsc.br
}

\begin{abstract}
Two males and one female of Holothuriophilus tomentosus (Ortmann, 1894) comb. nov. were collected in Enseada de Ratones, Florianópolis, Santa Catarina, in southern Brazil. Since its original description, as Pinnaxodes tomentosus, this species has only been collected recently, from the Pontal do Daniela, also in Florianópolis. The previously unknown male is described and the female is redescribed herein. The characteristics of this material lead us to believe that Pinnaxodes tomentosus should be transferred to the genus Holothuriophilus Nauk, 1880.

KEY WORDS. New combination, rediscovery.
\end{abstract}

RESUMO. Dois machos e uma fêmea de Holothuriophilus tomentosus (Ortmann, 1894) comb. nov. foram coletados na Enseada de Ratones, Florianópolis, Santa Catarina, sul do Brasil. Desde sua descrição original, como Pinnaxodes tomentosus, esta espécie somente foi coletada recentemente no Pontal da Daniela, também em Florianópolis. O macho, ainda desconhecido, é descrito e a fêmea é redescrita. As características do material estudado nos leva a acreditar que Pinnaxodes tomentosus deve ser transferido para Holothuriophilus Nauk, 1880.

PALAVRAS CHAVE. Costa brasileira, nova combinação, redescoberta.

\begin{abstract}
Ortmann (1894) when describing Pinnaxodes tomentosus based on two females, gave its type locality as "Brasilien" with no information as to the exact locality. Since then the species has only been collected, from the Pontal do Daniela, Florianópolis, state of Santa Catarina, in the pallial cavity of Cyrtopleura costata (Linnaeus, 1758); and in August 2001 by the junior author (G.B.), who collected, also in Florianópolis (Fig. 1), two males and one female, all associated with the bivalve Anomalocardia brasiliana (Gmelin, 1791). Ortmann's description was extremely succinct and accompanied by few figures, besides being restricted only to the female. All the authors who have treated this species (Moreira 1901, Rathbun 1918, Coelho \& Ramos 1972, Schmitt et al. 1973, Melo 1996, Takeda \& Prince Masahito 2000) of necessity have based their interpretations on this breaf original description. Takeda \& Prince Masahito (2000) suggested that $P$. tomentosus might appropriately be transferred to the genus Holothuriophilus Nauk, but refrained from any action. The description of the male and redescription of the female supplied herein confirm this supposition.
\end{abstract}

Holothuriophilus tomentosus (Ortmann, 1894) comb. nov.

Pinnaxodes tomentosus Ortmann, 1894: 197, pl. 23, figs 9,9i; Moreira, 1901: 39; Rathbun, 1918: 178, fig. 113; Coelho \& Ramos, 1972: 197; Schmitt et al., 1973: 36; Melo, 1996: 427 [fig. and map]; Takeda \& Prince Masahito, 2000: 105.

Description of male. Carapace subcircular, with many punctations suggesting that pilosity has been lost, its greatest width slightly anterior to middle; posterior margin slightly convex and continuous; front slightly projecting, formed by two lobes separated by very shallow concavity; regions, except gastric region, poorly demarcated; orbits minute, the eyes filling their entire concavity (Fig. 2). Third maxilliped with propodite and dactylopodite spatulate, positioned side by side, but with dactylopodite not reaching extremity of propodite (Fig. 4); separation of ischiopodite from meropodite almost imperceptible. Chelipeds homochelous, their palms inflated mainly on the inner face, which is pilose; length of palm almost twice its height, broadened distally, upper and lower faces 


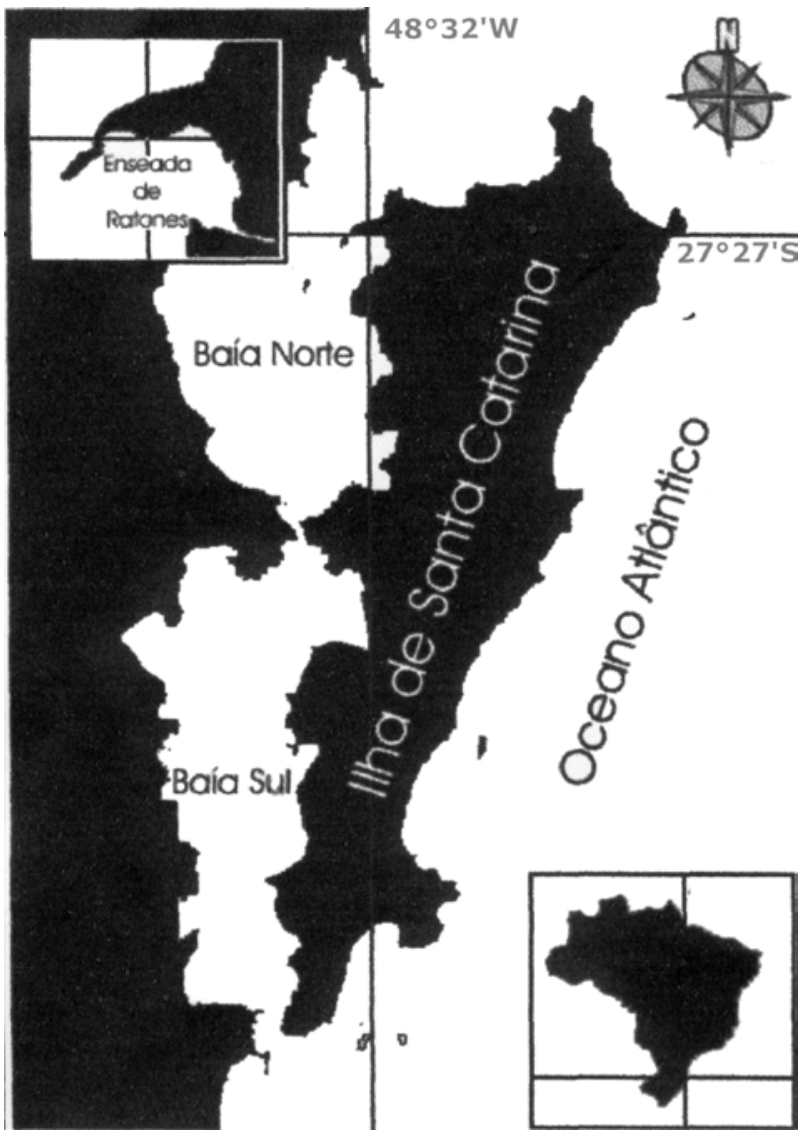

Figure 1. Map of the Enseada de Ratones, northwest of the Ilha de Santa Catarina.

convex; cutting face of dactylus with strong triangular tooth which lodges in the space between two other teeth situated on the fixed finger; a strong proximal hiatus between the fingers (Fig. 5), lengths of fingers slightly shorter than length of palm and strongly recurved, crossing at their extremities. Ambulatory legs relatively short, with propodus much longer than wide; dactyls of first three legs recurved, dactylus of last leg. nearly straight. Abdomen with all somites free; telson rounded and slightly longer than sixth somite, fourth abdominal somite with small central elevation (Fig.6).

Redescription of female. Carapace much less resistant and less rounded and circular than that of male, its contour almost pentagonal; front projecting less than that of male, bilobate, but with deeper concavity between the lobes (Fig. 3). Third maxilliped with propodite and dactylopodite spatulate, dactylopodite not reaching extremity of propodite; separation of ischiopodite from meropodite almost imperceptible. Chelipeds relatively longer and more slender than those of male; inner face of merus concave; fingers without hiatus, touching each other along their entire lengths, although the extremi- ties cross like those of male. Ambulatory legs with recurved dactyls, except dactylus of last leg. straight. Abdomen rounded, completely covering the sternum, all somites free; telson semicircular, as wide as sixth somite (Fig. 7).

Material examined. Brazil, Santa Catarina: Florianópolis (Enseada de Ratones, northwest sector of Ilha de Santa Catarina, 27 $27^{\prime}$ S: $48^{\circ} 32^{\prime} \mathrm{W}$ ), 2 males (MZUSP 15752) and 1 female (MZUSP 15753), G. Boehs leg., VIII.2001, associated with Anomalocardia brasiliana.

\section{DISCUSSION}

The genus Pinnaxodes was instituted by Heller (1865), with $P$. chilensis (H. Milne Edwards, 1837) as the type-species. Until recently, in addition to the type-species, five species were known: P. floridensis Wells \& Wells, 1961 [east coast of the United States (Florida)]; P. gigas Green, 1992 [eastern Pacific (Mexico)]; P. major Ortmann, 1894 [Indo-Pacific (Japan, Korea and Russia)]; P. mutuensis Sakai, 1939 [Indo-Pacific (Japan, Korea and Russia)] and P. tomentosus Ortmann, 1894 [western Atlantic (Brazil)].

The morphological differences among the genera Pinnaxodes; Pinnotheres Bosc, 1802; Archoteres Burger, 1895; Zaops Rathbun, 1900 and Holothuriophilus Nauk, 1880 are extremely subtle. The latter three genera were only recently resuscitated from the synonymy of Pinnotheres (Manning 1993). The systematic position of certain species of Pinnaxodes, including $P$. tomentosus, has long been subject to doubt, dating from the comment by RathBun (1918): "I think that this species is very likely a Pinnotheres".

According to MANNING (1993), the genus Holothuriophilus differs from Pinnaxodes in: a) the form of the carapace, with its greatest width anterior to the middle in Holothuriophilus and posterior to the middle in Pinnaxodes; b) in the proportions of the ambulatory legs, which are short and with short dactyls in Holothuriophilus and long and with long dactyls in Pinnaxodes; and c) in the structure of the third maxilliped, in which the ischiopodite and meropodite are fused in Holothuriophilus, and separated by a suture in Pinnaxodes.

Takeda \& Prince Masahito (2000) concluded that Pinnaxodes mutuensis Sakai, 1939, because of the morphology of its third maxilliped, should be transferred to the genus Holothuriophilus. They could not be as certain in relation to Pinnaxodes tomentosus, a little-known species, succinctly described and with figures showing little detail. However, these authors noted that it was possible to observe that the dactylopodite of the third maxilliped is somewhat spatulate, located side-by-side with the propodite, but not reaching the extremity of the propodite; and terminated their analysis sugesting that "its true systematic position may be in the genus Holothuriophilus, not in the genus Pinnotheres".

Through the description of the male and redescription of the female collected in Santa Catarina, we confirm the supposition of TAKeda \& Prince Masahito (2000). 

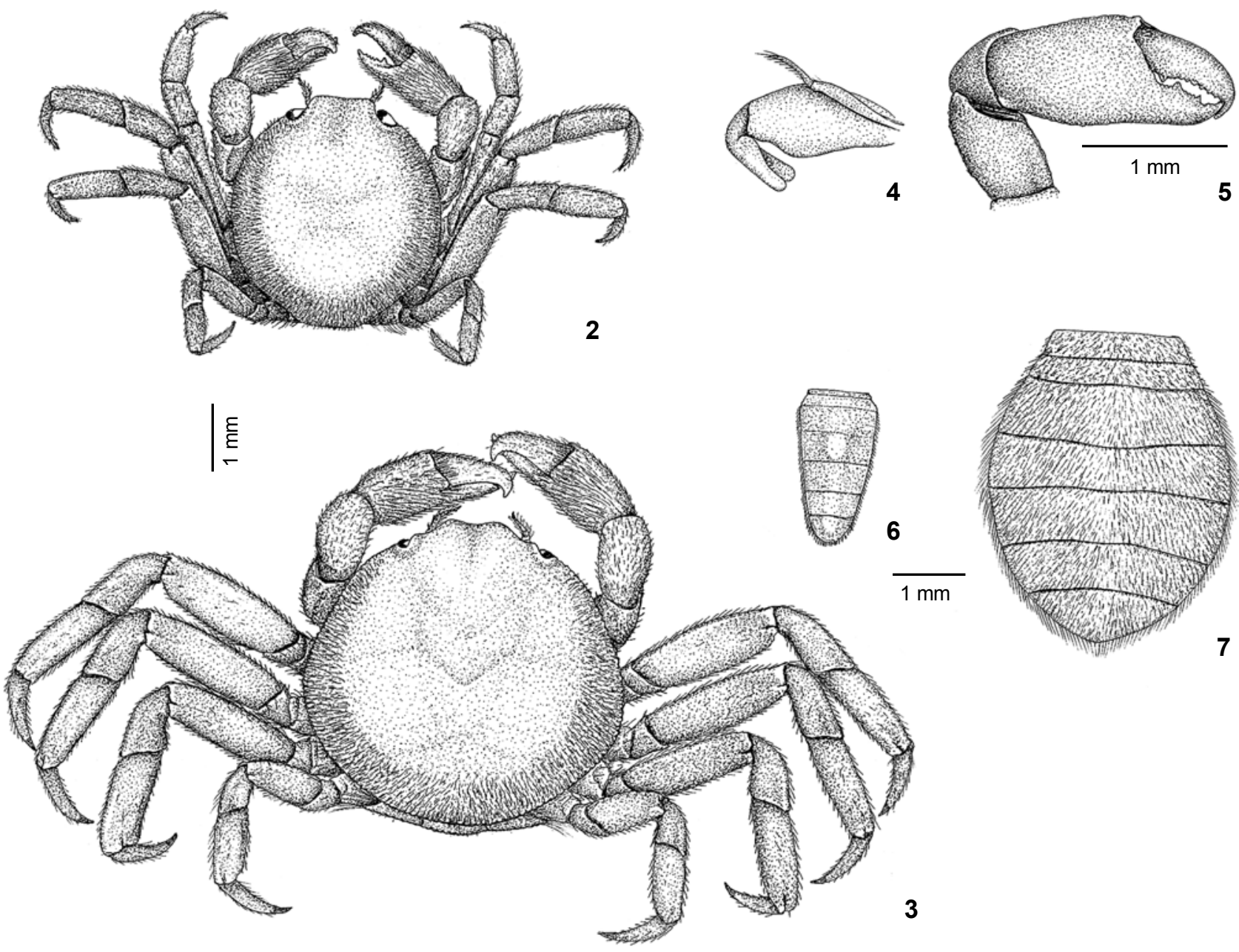

Figures 2-7. Holothuriophilus tomentosus comb. nov.: (2) male, dorsal view; (3) female, dorsal view; (4) male, third maxilliped; (5) male, right cheliped; (6) male, abdomen; (7) female, abdomen.

According to Manning (1993: 525), members of Pinnaxodes inhabit echinoids, while the species of Holothuriophilus live in holothurians. However, the two species transferred from Pinnaxodes to Holothuriophilus (H. mutuensis and H. tomentosus) have bivalve hosts: H. mutuensis in Modiolus modiolus (Linnaeus, 1758), Crenomytilus grayanus (Dunker, 1853) and Mytilus galloprovincialis Lamarck, 1819; and H. tomentosus, found in Santa Catarina associated with Cyrtopleura costata (Linnaeus, 1758) and Anomalocardia brasiliana (Gmelin, 1791).

\section{AKNOWLEDGMENTS}

We are indebted to Dr. Marcos Tavares, who provided helpful comments and suggestions.

\section{REFERENCES}

Coelho, P.A. \& M.A. Ramos. 1972. A constituição e a distribuição da fauna de Decápodos do litoral leste da América do Sul, entre as latitudes $5^{\circ} \mathrm{N}$ e $39^{\circ} \mathrm{S}$. Trabalhos Oceanográficos da Universidade Federal de Pernambuco, Recife, 13: 133-236.

Heller, C. 1865. Die Crustaceen. Reise der österreichichen Fregate "Novara" um die Erde in den Jahren 1857-1859 unter den Befehlen des Commodors B. von WullerstorfUrbair. Zoologische Theil. Crustaceen. Wien, vol. 2, pt. $3,280 \mathrm{p}$.

Manning, R.B. 1993. Three genera removed from the synonymy of Pinnotheres Bosc, 1802 (Brachyura: Pinnotheridae).

Revista Brasileira de Zoologia 21 (2): 229-232, junho 2004 
Proceedings of the Biological Society of Washington, Washington, 106 (3): 523-531.

MeLo, G.A.S. 1996. Manual de identificação dos Brachyura (caranguejos e siris) do litoral brasileiro. São Paulo, Plêiade/FAPESP, 603p.

MoreIRA, C. 1901. Contribuições para o conhecimento da fauna brazileira. Crustáceos do Brazil. Archivos do Museu Nacional do Rio de Janeiro, Rio de Janeiro, 11: 1-151.

Ortmann, A.E. 1894. Abtheilung: Brachyura (Brachyura Genuina Boas), III. Unterabtheilung: Cancroidea, 2. Section: Cancrinea, 2. Gruppe: Catometopa, Die Decapoden-Krebse des Strassburger Museums, mit besonderer Berüksichtigung der von Herrn Dr. Doderlein bei Japan und bei den Liu-Kiu Inseln gesammelten und zur Zeit im Strassburger Museum aufbewahrten Formen, VIII. Zoologische Jahrbücher, Abteilungen Systematik, Geographie der Tiere, Jena, 7: 683-772.

Rathbun, M.J. 1918. The Grapsoid crabs of America. Bulletin of the United States National Museum, Washington, 97: $1-445$.

Schmitt, W.L.; J.C. McCain \& E.S. Davidson. 1973. Crustaceorum Catalogus. Decapoda I. Brachyura I, pars 3, Pinnotheridae. H.E. Grunner \& L.B. Holthuis (Eds). Den Haag, W. Junk, 160p.

Takeda, M. \& Prince Masahito. 2000. Systematics notes on the Pinnotherid crabs of the genus Pinnaxodes (Crustacea: Decapoda: Brachyura). Bulletin of Natural Sciences of the Museum of Tokyo, ser. A, 26 (3): 99-112.

Received in 29.VIII.2003; accepted in 10.V.2004.

Revista Brasileira de Zoologia 21 (2): 229-232, junho 2004 